\title{
Proposals for consideration at IMC11 to modify provisions related solely to fungi in the International Code of Nomenclature for algae, fungi, and plants
}

\begin{abstract}
Seven proposals to modify the provisions of the International Code of Nomenclature for algae, fungi, and plants (ICN) at the $11^{\text {th }}$ International Mycological Congress (IMC11) in July 2018 had been received by the proscribed date of 1 March 2018. These proposals are formally presented together here. The topics addressed relate to the clarification of the meaning of "original material" in relation to the typification of sanctioned names, the indication of the nomenclatural status of sanctioned names in author citations, the use of DNA sequences as nomenclatural types, and the possibility of including repository identifiers as an alternative to author citations. A synopsis of the proposals will be provided during April, and the mycological community will be invited to provide a guiding vote up to 10 June 2018 . Final decisions on these proposals are to be made following debate at the Fungal Nomenclature Session of IMC11.
\end{abstract}

Key words: Author citations, DNA types, ICN, Identifiers, Nomenclature, Sanctioned names, Typification.

Article info: Accepted: 1 March; Published: 1 April 2018.

\section{INTRODUCTION}

The decision that all provisions related solely to fungi in the International Code of Nomenclature for algae, fungi and plants (ICN) should in future be amended at International Mycological Congresses (IMCs) and not International Botanical Congresses (IBCs) was made by the International Botanical Congress in Shenzhen in July 2017 (Hawksworth et al. 2017, Turland et al. 2017).

This means that proposals to change provisions solely related to fungi can be put forward for debate and decision by the Fungal Nomenclature Session (FNS) of IMC11 in Puerto Rico in July 2018. The procedure and timetable to be followed for making and dealing with any such proposals to IMC11 was explained in Hawksworth et al. (2017). The last date for the receipt of proposals by the Editor-in-Chief of IMA Fungus was advertised as 1 March 2018. By that date, four sets of proposals (seven individual proposals in total) had been received, and these are published here. An annotated synopsis to guide discussions will then be prepared for inclusion in IMA Fungus by 30 April 2018, and a guiding mail ballot will then run until 10 June 2018. The results of that guiding vote will be made available to the Fungal Nomenclatural Session (FNS) to be held during IMC11 on Thursday 19 July 2018.

The upcoming FNS will be able to consider any suggested amendments to these sets of proposals during the Session, but no completely new proposals can now be put forward.

While the Shenzhen edition of the ICN is not expected to be published until just before IMC11, the text has now been finalized and the proposals made here have been checked for confirmation with the precise numbering and wording that will appear in the new Shenzhen Code which is expected to be published in June (Turland et al. 2018). In the Shenzhen Code, provisions solely dealing with names of organisms treated as fungi are brought together in a new "Chapter F" in which Articles are numbered F.1 onwards.

Note that in the series of proposals that follow, proposed new text is in bold type, and any deleted text in strikethrough.

I am grateful to Tom W. May for looking over the proposals presented here as they went to press.

Hawksworth DL, May TW, Redhead SA (2017) Fungal nomenclature evolving: changes by the $19^{\text {th }}$ International Botanical Congress in Shenzhen 2017, and procedures for the Fungal Nomenclature Session at the $11^{\text {th }}$ International Mycological Congress in Puerto Rico 2018. IMA Fungus 8: 211-218.

Turland NJ, Wiersema JH, Munro AM, Deng Y-F, Zhang L (2017) XIX International Botanical Congress: report of Congress action on nomenclature proposals. Taxon 66: 1234-1245.

Turland NJ, Wiersema JH, Barrie FR, Greuter W, Hawksworth DL, et al. (eds) (2018) International Code of Nomenclature for algae, fungi, and plants (Shenzhen Code) adopted by the Nineteenth International Botanical Congress Shenzhen, China, July 2017. [Regnum Vegetabile no. 159.] Königstein: Koeltz Botanical Books.

David L. Hawksworth

\section{(F-001-002) PROPOSALS TO CLARIFY IF THE ELEMENTS FROM THE CONTEXT OF A SANCTIONING WORK ARE ORIGINAL MATERIAL}

\section{INTRODUCTION}

Two proposals are presented to clarify if the elements from the context of a sanctioning work (ECSW) are original material or not. This clarification is of crucial importance for the correct application of those Articles in which the expression "original material" is mentioned, among which are some of frequent use as, for example, those that regulate what hierarchy must be followed in choosing a lectotype (Art. 9.12), the designation of neotypes (Art. 9.13) or the superseding of lectotypes or neotypes (Art. 9.19).
To understand why these proposals are necessary, it is necessary to understand what was prescribed in Arts 7.8, 9.2 and Art. 9 Note 2 of the Vienna Code (McNeill et al. 2007).

Art. 7.8 established that "typification of names adopted in one of the works specified in Art. 13.1 (d), and thus sanctioned (Art. 15), may be effected in the light of anything associated with the name in that work". Art. 9.2 indicated that "the lectotype is an element of the original material designated as a nomenclatural type". Finally, Art. 9 Note 2 listed the elements that should be considered original material without explicitly including the 
ECSW and only made a brief citation in parentheses at the end of the paragraph "(but see also Art. 7.7, second sentence, and 7.8)" without any explanation or additional remark.

This lack of specificity in the Vienna Code as to whether the ECSW should be considered original material or not, and therefore may be designated according to Art. 9.2 as lectotypes, was likely the reason why subsequent typifications with ECSW were extremely rare.

Thereafter, in the Melbourne Code (McNeill et al. 2012), it was explicitly indicated in Art. 9.2 that the ECSW may be selected as lectotypes: "For sanctioned names, a lectotype may be selected from among elements associated with either or both the protologue and the sanctioning treatment (Article 9.10)". This same wording will be retained now in Art. 9.3 of the Shenzhen Code (Turland et al. 2018), although with the referenced Art. 9.10 having been moved to the consolidated fungal provisions in Chapter F as Art. F.3.9.

Likewise, to make more explicit the meaning of the cross reference "(but see Art. 7.7, 7.8, and 9.10)" at the end of Art. 9.3 of the Melbourne Code, a Note 4 was included: "For names falling under Art. 9.10, elements from the context of the protologue are original material and those from the context of the sanctioning work are considered as equivalent to original material". The previous Art. 9.3 will become Art. 9.4 of the Shenzhen Code, with Note 4 retaining this same wording now moved under Art. F.3.9 as Note 2. For clarity in this paper we will hereafter adopt the numbering of provisions in the new Shenzhen Code.

\section{BACKGROUND}

An exchange with some members of the Editorial Committee of the Melbourne Code, regarding the possible designation of a neotype for a name in which ECSW were available (Moreau et al. 2014), revealed that two possible interpretations of the current wording of Note 4 of Art. 9 were possible, which constitutes a source of potential nomenclatural instability. "Equivalent to original material" could be taken to mean that: (a) ECSW are original material; or (b) ECSW were not original material because, if they were, the addition "equivalent to" would be superfluous.

The implications of one interpretation or another are important because the concept of "original material", besides being mentioned in Shenzhen Code Art. 9.3 (definition of lectotype), 9.4 (definition of original material), and F.3.9 (type of sanctioned names) previously mentioned, also appears in other crucial Articles dealing with typification, such as Art. 9.12 (hierarchy of the different elements of the original material to be designated as lectotypes), 9.13 (conditions for the selection of a neotype) or 9.19 (supersession of lectotypes or neotypes).

In Art. 9.12, if the ECSW are original material, these elements would be included in the hierarchy of priorities to select a lectotype but if they are not original material, the ECSW would not be included as elements to be obligately designated as lectotype.

In Art. 9.13, if there are available ECSW and they are original material, a neotype could not be selected, but if they are not original material a neotype could be selected as done, for example, in Moreau et al. (2014).

In Art. 9.19, if there are available ECSW and they are original material, many previous neotypifications should be superseded if the name was sanctioned, but if they are not original material such neotypes cannot be rejected. For example, the neotype of Ramaria formosa (Pers. : Fr.) Quél. (Petersen 1976), was superseded due to the existence of ECSW and a lectotype was designated from the latter (Franchi \& Marchetti 2016) because ECSW were considered original material.

For all of the above, in order to contribute to nomenclatural stability, it is essential to know if the ECSW are "original material".

From an analysis of the wording of Art. 9.3 and the aforementioned Note 2 of Art. F.3, there seems to be a great reluctance to consider the ECSW as original material. We think this is because, instead of resorting to purely nomenclatural solutions, grammatical circumlocutions are used to prevent the association of ECSW, in a clear and direct way, with the expression “original material".

In Art. 9.3 the original material and the ECSW are mentioned in two independent sentences, when if it were considered that the ECSW are original material it would have been sufficient to quote the original material in the second, for example, replacing "among elements" by "original material": "For sanctioned names, a lectotype may be selected from the original material [among elements] associated with either or both the protologue and the sanctioning treatment (Art. F.3.9)" [bold added by us].

Note 2 of Art. F.3 also does not indicate clearly and directly that ECSW are original material. Here, the somewhat ambiguous expression "equivalent to original material" is used.

However, original material is now defined in the glossary as "the set of specimens and illustrations from which a lectotype may be chosen (see Art. 9.4, Notes 2 and 3, Art. F.3.9, and Note 2 for details), or the holotype (see Art. 9.1)". This definition had been changed from the Vienna Code to the Melbourne Code following the Proposal (222) of Perry (2010), thus avoiding the necessity of erecting the new term "sanctiotype", proposed in Redhead et al. (2010), and instead merging it under the definition of lectotype. Therefore, there should be no doubt that the ECSW are original material since they may be designated as lectotypes according to Art. 9.3.

Likewise, the Proposals (223-232) to amend the Articles of the Vienna Code to regulate the typification of names in sanctioning works (Redhead et al. 2010) suggest that the ECSW should be considered original material. In the Proposal Ex. 8ter. of Redhead et al. (2010) it is clear that if ECSW eligible as a type exist, a neotype could not be designated. Likewise, the sentence on page 1191 of those proposals is explanatory: "It is difficult to reconcile application of the term neotype with the current wording of Arts. 7.8 and $9.6 "$

Taking into account the need to unequivocally interpret whether the ECSW are original material or not, and to avoid any discrepancy between the Articles and the Glossary, two proposals are presented with two alternatives, in order to contribute to nomenclatural stability:

Alternative 1 in which the ECSW are original material.

In the hierarchical order of designation of a lectotype (Art. 9.12), ECSW would fall in the category of "uncited specimens and cited and uncited illustrations that comprise the remaining original material". A neotype could not be designated if ECSW are available (Art. 9.13), and all neotypes selected when ECSW are available would be rendered ineffective (Art. 9.19). Therefore, only a minor change in Art. F.3 Note 2 would be necessary (Prop. F-001 below).

Alternative 2 in which the ECSW would not be original material.

Art. 9.12 must then be changed to avoid a conflict with Art. 9.3 second sentence, as Art. 9.12 would not therefore include ECSW among the material eligible for selection as lectotype but Art. 9.3 states that a lectotype may be designated from ECSW. Article 9.13 
must be also changed (via a cross reference to Art. 9.12) to avoid a conflict with 9.19. Art. 9.13 states that a lectotype always takes precedence over a neotype, except as provided by Art. 9.16 and new Art. 9.19(c), but Art. 9.19 states that the authors who first designate a neotype must be followed. With the present wording, if an author first designates a neotype (Art. 9.19), this typification could not be followed if a subsequent author designates a lectotype (9.13) from ECSW that is not considered original material. It appears to be desirable that new neotypes could be designated (Art. 9.13), and those already designated could not be superseded (Arts. 9.12 and 9.19), even if ECSW are available. This interpretation would contribute to nomenclatural stability, as we know several cases in which a neotype was designated with available ECSW. Therefore, in this alternative, Art. 9.12 and Art. 9.13 must be changed, in addition to the re-wording in Proposal F-002 below. We note that if no neotype has been previously designated, one of the ECSW may still be designated as lectotype if the author who performs the typification wants to do so, for example, if there is any advantage of using a particular ECSW as type. This alternative would reconcile the application of the term neotype with the possibility of selecting ECSW as lectotypes, an interesting formula for typification of sanctioned names that has not yet been explored.

\section{PROPOSALS}

(F-001) Proposal to amend Art. F.3 Note 2 as follows:

"Note 2. For names falling under Art. F.3.9, both elements from the context of the protologue are original materiat and those from the context of the sanctioning work are eonsidered as equivalent to original material."

(F-002) Proposal to amend Art. F.3. Note 2 as follows:

"Note 2. For names falling under Art. F.3.9, an element from the context of a sanctioning work may be chosen as lectotype when no original material is available, except when a neotype has been previously designated for the same name."

This is an alternative to Prop F-001.

If F-002 is accepted, if will be necessary in due course for the Editorial Committee of the Shenzhen Code to make the following addition to Art. 9.13: "If no original material is extant or as long as it is missing, a neotype may be selected. A lectotype always takes precedence over a neotype, except as provided by Art. 9.16, 9.19(c), 9.12, and F. 3. Note 2."

\section{ACKNOWLEDGEMENTS}

We thank John Wiersema (USDA/ARS National Germplasm Resources Laboratory) for his useful comments and improvements to this manuscript and for adapting the proposal to the new numbering of the Articles and Notes of the Shenzhen Code.

\section{REFERENCES}

Franchi P, Marchetti M (2016) Novità nomenclaturali - Nomenclatural novelties. Rivista di Micologia 59: 321-327.

McNeill J, Barrie FR, Burdet HM, Demoulin V, Hawksworth DL et al. (eds) (2006) International Code of Botanical Nomenclature (Vienna Code) adopted by the Seventeenth International Botanical Congress Vienna, Austria, July 2005. [Regnum Vegetabile no. 146.] Ruggell: A. R. G. Ganter Verlag.

McNeill J, Barrie FR, Buck WR, Demoulin V, Greuter W, et al. (eds.) (2012) International Code of nomenclature for algae, fungi, and plants (Melbourne Code) adopted by the Eighteenth International Botanical Congress

Melbourne, Australia, July 2011. [Regnum Vegetabile no. 154.] Königstein: Koeltz Scientific Books.

Moreau P-A, Bellanger J-M, Clowez P, Courtecuisse R, Hansen K et al. (2014) (2289) Proposal to conserve the name Morchella semilibera against Phallus crassipes, P. gigas and P. undosus (Ascomycota). Taxon 63: 677-678.

Perry G (2010) (215-222) Proposals on original material. Taxon 59: 19091910.

Petersen RH (1976) Contribution toward a monograph of Ramaria III. $R$. sanguinea, $R$. formosa, and two new species from Europe. American Journal of Botany 63: 309-316.

Redhead SA, Norvell LL, Pennycook SR (2010) (223-232) Proposals to amend Articles regulating the typification of names in sanctioning works. Taxon 59: 1910-1913.

Turland NJ, Wiersema JH, Barrie FR, Greuter W, Hawksworth DL, et al. (eds) (2018) International Code of Nomenclature for algae, fungi, and plants (Shenzhen Code) adopted by the Nineteenth International Botanical Congress Shenzhen, China, July 2017. [Regnum Vegetabile no. 159.] Königstein:

Koeltz Botanical Books.

Luis A. Parra ${ }^{1}$ and Juan C. Zamora ${ }^{2}$ ${ }^{1}$ Avenida Padre Claret 7, 5 G, 09400 Aranda de Duero, Burgos, Spain

${ }^{2}$ Museum of Evolution, Uppsala University, Norbyvägen 16, SE-752 36 Uppsala, Sweden Corresponding author e-mail: jcsenoret@gmail.com

\section{(F-003-004) PROPOSALS TO SIMPLIFY THE INDICATION OF THE NOMENCLATURAL STATUS OF SANCTIONED NAMES}

\section{BACKGROUND}

When the later starting points for the nomenclature of selected groups of fungi were abandoned at the Sydney IBC in 1981 and reverted to 1 May 1753, the concept of sanctioned names was introduced to protect names adopted in the former starting-point works against any competing names, whether they were included in the sanctioning works or not (Van Warmelo 1979, Demoulin et al. 1981). This has proved to be a major contribution to the stability of fungal names, and at a stroke removed the need for numerous conservation proposals.

The use of a colon, “:”, in author citations to indicate the special sanctioned status of names, was included in the Sydney Code, but as a Recommendation rather than an Article. The possibility of utilizing the colon in this way had been explored by a committee mandated to look into later starting issues by the Nomenclatural 
Secretariat established by the first International Mycological Congress (IMC1) at Exeter in 1971. The report of that committee was considered by the subsequent Congress, IMC2 in Tampa, Florida, in 1977, where it was decided not to commend the use of any notation because of the complexities and misunderstandings foreseen as inherent in its' use. It was not therefore provided for in the proposals that came from IMC2 (Van Warmelo 1979). This decision was not, however, supported by all members of the Nomenclature Committee for Fungi and Lichens, and this resulted in a proposal to make the use of ":" mandatory adopting a wording by Holm (Petersen 1981); the idea of the notation was accepted, but downgraded to a Recommendation during the debate at the Sydney Congress (Greuter \& Voss 1982: 49-50). It was soon appreciated how complex this would be to apply in practice when the sanctioned name was a combination, or when the sanctioned name was moved from genus to genus, and guidance as how to proceed was quickly prepared by Korf (1982). His recommendations were not, however, found to be easy to follow and this has continued to be a source of confusion, and as currently worded can be excessively clumsy when correctly applied, as indicated in the current wording of Example 2 (see below).

Almost 35 years after the introduction of the convention into the Code, and despite the further guidance provided by Korf (1996), sanctioned names are still being cited by some mycologists only with the bibliographic details, author, and date of the sanctioning work, and not with the actual place of valid publication and date of the names. This is unfortunate as the date of valid publication, and often also the typification, relate to the original author and name not to the sanctioning author or place of sanctioning. Further, as this is a Recommendation, and so something that need not be followed, many mycologists have chosen not to use the colon because of the confusions and clumsy citations that can result. The colon has consequently not been adopted in editions of Ainsworth \& Bisby's Dictionary of the Fungi, the published catalogue of fungal names (Index of Fungi), or nomenclator databases for the names of fungi such as Index Fungorum.

This notation is the only instance in the whole of biological nomenclature where the nomenclatural status of a name can form a part of an author citation. In all other cases where names are invalid, illegitimate, conserved, rejected, etc., the status is indicated only where it is considered useful and then by the use of the abbreviations " nom. inval., "nom. illegit., "nom. cons.", "nom. rej.", etc. This way of indicating the status of names is well established but generally restricted to presentations of formal taxonomic treatments where it is appended after a bibliographic reference to the place of publication of the name - never routinely as an integral part of author citations.

The suggestion that the use of ":" be discontinued was included in a questionnaire to mycologists attending IMC10 in Bangkok in 2014, when $71.8 \%$ of those responding favoured deletion of the Recommendation if this was linked to the inclusion of sanctioned names in the concept of protected names (Redhead et al. 2014). In the course of discussions in the Nomenclatural Sessions during that congress, Tom May indicated that he was convinced the colon should be dropped, and as an alternative proposed the use of "nom. sanct." in formal citations, an alternative that was supported by Nicholas Turland (who was to be the Rapporteur général for the Shenzhen Code); see the report in Redhead et al. (2014). The issue was then looked into by the International Commission on the
Taxonomy of Fungi (ICTF), with $95 \%$ of the 20 members voting supporting the deletion of the colon in favour of "nom. sanct.". A formal proposal to make this change was therefore published (Hawksworth 2015), but the Shenzhen Congress decided not to follow that suggestion, primarily because the mycologists present were divided on the matter, but instead they recommended the use of "nom. sanct." as an alternative to the ":" (Hawksworth et al. 2017, Turland et al. 2017) which has now been incorporated into the current Code (Turland et al. 2018).

The situation of having alternatives in a Recommendation provides additional obfuscation, and so proposals are now made to discontinue the colon alternative in line with the views expressed at IMC10 and overwhelming supported by the ICTF. This would also bring the expression of this form of nomenclatural status into line with that used for all other indications of the status of a name.

\section{PROPOSALS}

\section{(F-003) Amend Rec. F.3A as follows:}

F.3A.1. After a sanctioned name (Art. F.3.1), either “: Fr." or “: Pers." (to indicate the sanctioning author Fries or Persoon) or the abbreviation "nom. sanct." (nomen sanctionatum) should may be added in a formal citation, together with the citation of the place of sanctioning if when it is considered desirable useful to indicate the nomenclatural status of the name. In a formaleitation of a new combination based either on a sanetioned name or on the basionym of a sanetioned name, ": Fr." or ": Pers." should be added within the parentheses after the author(s) of the basionym (Art. 49.1)." [footnote $]^{+}$In this Code and its Appendices, sanetioning is indicated by ": Fr." or ": Pers."

\section{(F-004) Revise Examples 1 and 2 in Rec. F.3A as follows:}

Ex. 1. Boletus piperatus Bull. (Herb. France: t. 451, fig. 2. 1790) was adopted in Fries (Syst. Mycol. 1: 388. 1821) and was thereby sanctioned. It can be cited as either $B$. piperatus Bull. : Fr. or $B$. piperatus Bull., nom. sanct. when it is useful to indicate the nomenclatural status of the name.

Ex. 2. Agaricus compactus [unranked] sarcocephalus (Fr.) Fr. was sanctioned when adopted by Fries (Syst. Mycol. 1: 290. 1821). That status can be indicated by citing it as either $A$. [unranked] sarcocephatus (Fr.: Fr.) Fr.: Fr. or $A$. compactus [unranked] sarcocephalus (Fr.) Fr., nom. sanct. The designation ": Frnom. sanct." is not to be added when citing its basionym $A$. sarcocephalus Fr. (Observ. Mycol. 1: 51. 1815) and nor to, but it can be added when eiting subsequent combinations such as Psathyrella sarcocephala (Fr. Fr.) Singer (in Lilloa 22: 468. 1949).

\section{REFERENCES}

Demoulin V, Hawksworth DL, Korf RP, Pouzar Z (1981) A solution of the starting point problem in the nomenclature of fungi. Taxon 30: 52-63.

Greuter W, Voss EG (1982) Report on botanical nomenclature - Sydney 1981. Englera 2: 1-124.

Hawksworth DL (2015) Proposals to clarify and enhance the naming of fungi under the International Code of Nomenclature for algae, fungi, and plants. IMA Fungus 6: 199-205; Taxon 64: 858-862.

Hawksworth DL, May TW, Redhead SA (2017) Fungal nomenclature evolving: changes adopted by the $19^{\text {th }}$ International Botanical Congress in Shenzhen 
2017, and procedures for the Fungal Nomenclature Session at the $11^{\text {th }}$ International Mycological Congress in Puerto Rico 2018. IMA Fungus 8: 211-218.

Korf RP (1982) Citation of authors' names and the typification of names of fungal taxa published between 1753 and 1832 under the changes in the Code of nomenclature enacted in 1981. Mycologia 74: 250-255.

Korf RP (1996) Simplified author citations for fungi and some old traps and new complications. Mycologia 88: 146-150.

Petersen RH (1981) Report of the Committee for Fungi and Lichens. Taxon 30: $472-473$.

Redhead SA, Demoulin V, Hawksworth DL, Seifert KA, Turland NJ (2014) Fungal nomenclature at IMC10: report of the Nomenclature Sessions. IMA Fungus 5: 449-462.

Turland NJ, Wiersema JH, Barrie FR, Greuter W, Hawksworth DL, et al. (eds) (2018) International Code of Nomenclature for algae, fungi, and plants
(Shenzhen Code) adopted by the Nineteenth International Botanical Congress Shenzhen, China, July 2017. [Regnum Vegetabile no. 159.] Königstein:

Koeltz Botanical Books.

Turland NJ, Wiersema JH, Monro AM, Deng Y-F, Zhang L (2017) XIX International Botanical Congress: report of Congress action on nomenclatural proposals. Taxon 66: 1234-1245.

Van Warmelo KT (1979) Proposals for the modification of the Code of Botanical Nomenclature: IMC2 proposals. Taxon 28: 424-431.

David L. Hawksworth Comparative Plant and Fungal Biology, Royal Botanical Gardens, Kew, Richmond, Surrey TW9 3DS, UK; Department of Life Sciences, The Natural History Museum, Cromwell Road, London SW7 5BD, UK; and Jilin Agricultural University, Changchun, Jilin 130118, China Corresponding author e-mail: d.hawksworth@kew.org

\section{(F-005-006) PROPOSALS TO PERMIT DNA SEQUENCE DATA TO BE USED AS TYPES OF NAMES OF FUNGI}

\section{BACKGROUND}

The need for some provision in the ICN to deal with the naming of the numerous novel fungi being discovered among molecular sequences recovered from environmental samples is increasingly pressing, and affects fungi from the rank of phylum down to species. The problem is most acute in the case of voucherless sequences obtained from next-generation sequencing of environmental samples.

The Code does not prohibit the use of any category of characters for the separation of taxa, that being a matter of taxonomy and not of nomenclature; thus DNA sequence data as a sole diagnostic character are acceptable. It is the situation encountered with voucherless environmental sequence data that needs to be addressed. In order to remedy this, we propose that DNA sequence data alone should be permissible as types for fungi when no physical specimen or illustration is available for technical reasons.

The need to take action on this matter was already emphasized in the Amsterdam Declaration on Fungal Nomenclature (Hawksworth et al. 2011), and also elsewhere at that time (Hibbett et al. 2011, Taylor 2011). A poll conducted amongst mycologists attending IMC10 in Bangkok in 2014, found that $44 \%$ of Congress members responding supported the concept of naming such taxa (Redhead et al. 2014). A series of proposals to permit DNA sequence data to be used as types for names of fungi in the absence of any specimens which aimed to address this need was presented to the Shenzhen IBC (Hawksworth et al. 2016). Nevertheless, some mycologists have introduced scientific names based on sequences alone (De Beer et al. 2016, Lücking \& Moncada 2017), even though the absence of a physical type or an illustration meant that those names were invalid.

The formal set of proposals generated considerable debate in Shenzhen (Hawksworth et al. 2017), and as the issue was potentially relevant to other groups of organisms, the IBC decided to set up a Special-purpose Committee on DNA Sequences as Types (Turland et al. 2017); that Committee is due to report to the next IBC in Rio de Janeiro in 2023. The rate of accumulation of novel sequences of fungi from environmental samples is, however, currently exponential and we do not consider the issue, in so far as it relates to fungi, can be left until IMC12 in 2022. The issue of this "dark matter", as it was referred to by Ryberg \& Nilsson (2018), has to be addressed now as a matter of increasing urgency.

For further background information relevant to this proposal see Hawksworth et al. (2016) and Hawksworth \& Lücking (2017). A further contribution by Lücking \& Hawksworth is currently under review and expected shortly.

In order to ensure that the matter is debated, and hopefully a solution found, at IMC11, we re-present the proposals made to the Shenzhen IBC here as a starting point for that discussion. We anticipate that some amendments to these will be suggested and considered at the FNS. Authors are already free to use any characters, including molecular sequences, in diagnoses, but are precluded from allocating names to environmental sequences obtained through voucherless sequencing techniques by the inability to designate a physical holotype corresponding to particular sequence data. The current Code is, therefore, currently failing to meet the needs of the mycological community.

\section{PROPOSALS}

(F-005) Insert a new paragraph after Art. F.4.1 as follows:

"F.4.2. In fungi, when DNA sequence data corresponding to a new taxon have been detected, but no physical specimen has been found to serve as the type of the name of the new taxon (Art. 8.1-8.4), the type may be composed of DNA sequence data deposited in a public repository."

(F-006) Add a new Recommendation F.4A as follows:

"F.4A.1. When the type is composed only of DNA sequence data (Art. F.4.2), the new taxon should be described with reference to a published phylogenetic analysis; both the phylogenetic tree and the DNA sequence alignment that was used to create the phylogenetic tree should be deposited in a 
publicly accessible repository."

"F.4A.2. A new taxon typified only by DNA sequence data should be represented by multiple sequences obtained in independent studies, of which one is designated as the holotype."

"F4A.3. DNA sequence data used for typification should be drawn from the molecular regions that are appropriate for delimiting species, based on prevailing best practices as determined by the relevant taxonomic communities."

Should these proposals pass, the Editorial Committee for the next edition of the ICN will need to consider making minor changes in Art. 9.1 and Art. 40, in particular in Arts. 40.2, 40.3, 40.4, and perhaps 40.5 , to ensure consistency with them, as well as adding a "but see" cross-reference in Art. 8.1.

\section{REFERENCES}

De Beer ZW, Marincowitz S. Duong TA, Kim JJ, Rodrigues A, Wingfield MJ (2016) Hawksworthiomyces gen. nov. (Ophiostomatales), illustrates the urgency for a decision on how to name novel taxa known only from environmental nucleic acid sequences (ENAS). Fungal Biology 120: $1323-1340$

Hawksworth DL, Crous PW, Redhead SA, Reynolds DR, Samson RA, et al. (2011) The Amsterdam Declaration on Fungal Nomenclature. IMA Fungus 2: 105-112.

Hawksworth DL, Hibbett DS, Kirk PM, Lücking R (2016) (308-310) Proposals to permit DNA sequence data to serve as types of names of fungi. Taxon 65:899-900.

Hawksworth DL, Lücking R (2017) Fungal diversity revisited: 2.2 to 3.8 million species. Microbiology Spectrum 5(4):FUNK-0052-2016. doi:10.1128/microbiolspec.FUNK-0052-2016.

Hawksworth DL, May TW, Redhead SA (2017) Fungal nomenclature evolving: changes adopted by the $19^{\text {th }}$ International Botanical Congress in Shenzhen 2017, and procedures for the Fungal Nomenclature Session at the $11^{\text {th }}$ International Mycological Congress in Puerto Rico 2018. IMA Fungus 8: 211-218.
Hibbett DS, Ohman A, Glotzer D, Nuhn M, Kirk P, Nilsson RH (2011) Progress in molecular and morphological taxon discovery in Fungi and options for formal classification of environmental sequences. Fungal Biology Reviews 25: 38-47.

Lücking R, Moncada M (2017) Dismantling Marchandiomphalina into Agonimia (Verrucariaceae) and Lawreymyces gen. nov. (Corticiaceae): setting a precedent to the formal recognition of thousands of voucherless fungi based on type sequences. Fungal Diversity

Redhead SA, Demoulin V, Hawksworth DL, Seifert KA, Turland NJ (2014) Fungal nomenclature at IMC10: report of the Nomenclature Sessions. IMA Fungus 5: 449-462.

Ryberg M, Nilsson RH (2017) New light on names and naming of dark taxa. MycoKeys 30: 31-39.

Taylor JW (2011) One Fungus = One Name: DNA and fungal nomenclature twenty years on. IMA Fungus 2: 113-120.

Turland NJ, Wiersema JH, Monro AM, Deng Y-F, Zhang L (2017) XIX International Botanical Congress: report of Congress action on nomenclatural proposals. Taxon 66: 1234-1245.

David L. Hawksworth ${ }^{1-3}$, David S. Hibbett ${ }^{4}$, Paul M. Kirk ${ }^{1,5}$, and Robert Lücking ${ }^{6}$

${ }^{1}$ Comparative Plant and Fungal Biology, Royal Botanic Gardens, Kew, Richmond, Surrey TW9 3DS, UK

${ }^{2}$ Department of Life Sciences, The Natural History Museum, Cromwell Road, London SW7 5BD, UK ${ }^{3}$ Jilin Agricultural University, Changchun, Jilin 130118, China ${ }^{4}$ Biology Department, Clark University, 950 Main Street, Worcester, MA 01610, USA

${ }^{5}$ State Key Laboratory of Mycology, Institute of Microbiology, Chinese Academy of Sciences, Beijing 100101, China

${ }^{6}$ Botanischer Garten und Botanisches Museum Berlin, Freie Universität Berlin,

Königin-Luise-Straße 6-8, 14195 Berlin, Germany Corresponding author e-mail: d.hawksworth@kew.org

\section{(F-007) PROPOSAL TO RECOMMEND THE USE OF AN IDENTIFIER AS AN ALTERNATIVE TO THE CITATION OF THE AUTHORS OF FUNGAL NAMES \\ BACKGROUND}

The length of author name strings has significantly increased in the last decades, which can be demonstrated by an analysis of names in "LIAS names - A Database with Names of Lichens, Lichenicolous Fungi and Non-Lichenized Ascomycetes" (www.liasnames.lias.net).

In addition, ambiguity of author name citation has increased because of variations in author name abbreviation and incomplete or incorrect citation of authors' names. It is therefore suggested that in non-taxonomic scientific publications, author citations of fungal names, where considered desirable, should be replaced by taxon name identifiers as issued by the designated registration repositories. Since 2012, registration of new fungal names has been compulsory under the ICN. A consortium for the registration of fungal names, comprising the three repositories Fungal Names, Index Fungorum, and MycoBank, is in place. This consortium organises the registration of new names and provides stable and persistent six digit identifying codes (i.e. taxon name identifiers) that are assigned to newly published taxon names. The identifiers used by each partner in the consortium come from separate defined number ranges and are therefore unique within the consortium. The six digits are used as part of stable Universal Resource Identifiers (URIs) in the schemes provided by two partners of the consortium, Index Fungorum and MycoBank, i.e. http://www.indexfungorum.org/Names/NamesRecord. asp?RecordID=identifier and http://www.mycobank.org/MB/ identifier. The identifying code of six digits could also function to replace author name strings, because it can serve as a direct link to database entries in the repositories that contain those author name string and other key nomenclatural information on the taxon. Advantages of such a practice are explained in detail by Rambold et al. (2017).

For example, one of the longest author name strings for a combination found in LIAS, Massjukiella kaernefeltii (S. Y. Kondr., 
D. J. Galloway \& Goward) S. Y. Kondr., Fedorenko, S. Stenroos, Kärnefelt, Elix, Hur \& A. Thell, published in 2012, comprises 108 letters (including spaces). In MycoBank an author name string with as many as 210 letters (including spaces) was found: Carlosrosaea vrieseae (Landell, L.R. Brandão, S.V. Safar, F.C. Gomes, C.R. Félix, A.R. Santos, D.M. Pagani, J.P. Ramos, Broetto, T. Mott, Vainstein, P. Valente \& C.A. Rosa) A.M. Yurkov, Xin Zhan Liu, F.Y. Bai, M. Groenew. \& Boekhout (www.mycobank.org/MB/814757).

While we recognize that the current Art. 46 recommends the use of "et al." after the first author when there are more than two, in practice many authors persist in citing all those involved. As an alternative, we suggest the following new Recommendation be added under a new Article F.10 headed "Citation of authors of fungal names".

\section{PROPOSAL}

(F-007) Add a new Recommendation and examples under a new heading Citation of Authors of Fungal names as follows:

"F.10A. For names of organisms treated as fungi, the identifier for the name of a taxon issued by an ICN-recognized registration repository (see also Art. 22.1 and 26.1) may be used in place of the author citation of the name (but not to replace the name itself). The identifier should be preceded by a hash $(\#)$ and enclosed in square brackets. In electronic publications this identifier should be directly linked out to its stable representation (Universal Resource Indicator) in one of the registration repositories."

"Ex. 1. Astrothelium meristosporoides [\#816706]; the link out for the latter identifier would be www.mycobank.org/
MB/816706 or, alternatively, http://www.indexfungorum.org/ Names/NamesRecord.asp?RecordID=816706."

"Ex. 2. Lecanora varia [\#389546]; the link out for the latter identifier would be http://www.indexfungorum.org/Names/ NamesRecord.asp? RecordID $=389546$ or, alternatively, www. mycobank.org/MB/389546."

\section{REFERENCE}

Rambold G, Bensch K, Kirk PM, Yao Y-J, Robert V, et al. (2017) Citation of a taxon name identifier issues by the ICN-recognized registration repositories instead of taxon name author citation. Taxon 66: 1200-1203.

Gerhard Rambold ${ }^{1}$, Konstanze Bensch ${ }^{2,5}$, Paul M. Kirk ${ }^{3,4}$, Yi-Jian Yao $^{4}$, Vincent Robert ${ }^{5}$, and Dagmar Triebel ${ }^{2}$ ${ }^{1}$ Department of Mycology, University of Bayreuth, Universitätsstraße 3, 95440 Bayreuth, Germany

${ }^{2}$ SNSB IT-Center, Botanische Staatssammlung München, Menzinger Straße 67, 80638 München, Germany ${ }^{3}$ Biodiversity Informatics \& Spatial Analysis, Royal Botanic Gardens, Kew, Richmond, Surrey TW9 3DS, UK

${ }^{4}$ State Key Laboratory of Mycology, Institute of Microbiology, Chinese Academy of Sciences, Beijing 100101, China ${ }^{5}$ Westerdijk Fungal Biodiversity Institute, Uppsalalaan 8, 3584 CT Utrecht, The Netherlands Corresponding author e-mail: Konstanze Bensch, bensch@bsm. mwn.de 